\title{
Defined Observation Method Code
}

National Cancer Institute

\section{Source}

National Cancer Institute. Defined Observation Method Code. NCI Thesaurus. Code C93778.

A coded value specifying the technique that is used for the observation. 